\title{
PENGARUH PUPUK KOMPOS DARI LIMBAH PADAT INDUSTRI PULP DAN KERTAS TERHADAP PERTUMBUHAN EUCAL YPTUS PELLITA
}

\author{
Muhammad Reza Lesmana ${ }^{1}$, Ambar Tri Ratnaningsih ${ }^{2}$, Eni Suhesti ${ }^{2}$ \\ 1. Mahasiswa Fakultas Kehutanan Universitas Lancang Kuning \\ 2. Staff Pengajar Fakutas Kehutanan Universitas Lancang Kuning \\ Jl. Yos Sudarso Km. 8 Rumbai. Pekanbaru \\ Email:Reza_1108@yahoo.com,ambar@unilak.ac.id dan suhestieni@unilak.ac.id
}

\begin{abstract}
The pulp and paper industry produces liquid waste in its production process. Liquid waste in solid form of sludge can be utilized as compost fertilizer. Research conducted at PT. Indah Kiat Pulp and PT Arara Abadi Rasau Kuning District, Riau Province. The aim of this research is to know the effect of compost fertilizer from pulp and paper industry waste on Eucalyptus pellita growth and to determine the most appropriate dose of compost for growth of Eucalyptus pellita. The research method was done by applying compost in 3-month Eucalyptus pellita with dosage of o gram, 750 gram, 1000 gram and 1250 gram. Parameters measured over 3 months were plant height, plant diameter and number of leaves. Provision of compost fertilizer from pulp and paper industry waste has no significant effect on Eucalyptus pellita growth. Visually, the most appropriate dose of compost for the growth of Eucalyptus pellita is a dose of 1000 grams.
\end{abstract}

Keywords: Compost fertilizer, sludge, fertilizer dose, Eucalyptus pellita

\section{PENDAHULUAN}

Industri pulp dan kertas merupakan salah satu industri di Indonesia yang memiliki prospek yang cerah di masa mendatang dan memberikan kontribusi yang cukup besar dalam perekonomian Indonesia. Terlebih lagi melalui keberadaan Hutan Tanaman Industri (HTI) yang menyuplai kebutuhan bahan baku pabrik pulp dan kertas dan ketersediaan
Sumber Daya Manusia (SDM) untuk melakukan proses produksi secara efisien mendorong pertumbuhan industri pulp dan kertas Indonesia.

Perkembangan industri tidak hanya meningkatkan kesejahteraan masyarakat saja, namun juga dapat menimbulkan dampak negatif. Hal ini disebabkan karena selain menghasilkan 
produk sebagai hasil akhir proses produksi, kegiatan tersebut juga menghasilkan limbah sebagai sisa proses produksi. Limbah industri akan berdampak negatif bagi lingkungan jika tidak diolah dengan tepat karena akan menimbulkan pencemaran lingkungan dan selanjutnya dapat membahayakan kehidupan dan kesehatan makhluk hidup.

Limbah Industri pulp dan kertas terdiri dari tiga jenis yaitu cair, padat dan gas. Limbah cair adalah air limbah yang dihasilkan dari proses pembuatan pulp dan kertas yang menggunakan air sebagai pelarut bahan kimia atau untuk proses pencucian. Salah satu teknologi pengolahan limbah cair adalah secara biologis dengan memanfaatan mikroorganisme atau bakteri untuk menurunkan kadar pencemaran limbah tersebut. Mikroorganisme atau Bakteri diberi nutrisi yang diperlukan bagi kehidupan organisme. Setelah diproses lebih lanjut, hasil akhir dari pengolahan limbah cair adalah sludge atau lumpur (Limbah Padat). Lumpur dari pengolahan limbah cair mengandung bahan organik sisa dari proses pembuatan pulp dan kertas serta mikroorganisme atau bakteri. Salah satu cara memanfaatkan limbah padat (sludge) industri pulp dan kertas yang mudah dan dapat dikembangkan secara sederhana yaitu melalui proses pengomposan dengan hasil akhir berupa pupuk kompos atau pupuk organik. Hal ini menjadi dasar karena limbah padat industri pulp dan kertas mengandung bahan organik sekitar $60 \%$. Selain itu limbah tersebut mengandung sumber karbon yang diperlukan bagi mikroorganisme dalam proses pengomposan. Pemanfaatan limbah pada dari industri pulp sebagai pupuk organik telah diteliti oleh Komarayati dan Gusmailina (2007).

Provinsi Riau merupakan salah satu provinsi yang memiliki areal Hutan Tanaman Industri (HTI) yang luas dan berdiri dua pabrik pulp dan kertas. Limbah yang dihasilkan dari kegiatan produksi dapat dimanfaatkan menjadi kompos untuk tanaman di HTI. Pemanfaatan sludge sebagai 
kompos untuk tanaman di $\mathrm{HTI}$ akan memberi pengaruh terhadap pertumbuhan tanaman disamping dosis yang akan memberikan pengaruh bagi pertumbuhan tanaman. Penelitian ini bertujuan untuk mengatuhui pengaruh pemberian pupuk kompos dari limbah industri pulp dan kertas terhadap pertumbuhan Eucalyptus pellita dan menentukan dosis pupuk kompos yang paling tepat bagi pertumbuhan Eucalyptus pellita.

\section{METODE PENELITIAN}

Penelitian dilaksanakan di PT. Arara Abadi, Distrik Rasau Kuning Kecamatan Tualang Kabupaten Siak Provinsi Riau. Sludge yang digunakan berasal dari pabrik PT. Indah Kiat Pulp dan Paper Tbk. Provinsi Riau dan telah diolah menjadi pupuk kompos. Untuk mengetahui pengaruh pemberian pupuk kompos terhadap pertumbuhan tanaman Eucalyptus pellita, dilakukan percobaan dengan mengaplikasikan pupuk kompos berbahan baku sludge terhadap tanaman Eucalyptus pellita yang berumur 3 bulan yang di tanam di areal HTI. Pemberian pupuk kompos dilakukan dengan 4 dosis yaitu 0 gr, 750 gr, 1.000 gr dan $1.250 \mathrm{gr}$.

Bibit Eucalyptus pellita yang berumur 3 bulan dengan tinggi 20$30 \mathrm{~cm}$ ditanam dengan lubang tanam berukuran adalah $30 \times 20 \times$ $20 \mathrm{~cm}$ dengan jarak tanam $2 \mathrm{~m} \times 2$ $\mathrm{m}$ dan diberi pupuk kompos sesuai dengan perlakuan dosis pupuk. Selama 3 bulan dilakukan pengamatan pertumbuhan berupa tinggi dan diamater tananam serta jumlah daun. Pengamatan terhadap tinggi tanaman dilakukan dengan mengukur tanaman dari pangkal batang sampai batas daun tertinggi secara vertikal menggunakan meteran/penggaris. Pengamatan terhadap diameter batang dilakukan dengan mengukur sisi batang yang berukuran maksimum menggunakan jangka sorong. Pengamatan terhadap jumlah daun tanaman dengan menghitung jumlah helai daun pada tiap tanaman. Pengamatan dilakukan 1 kali setiap 2 minggu. 
Untuk mengetahui pengaruh dosis pupuk kompos terhadap pertumbuhan pohon maka data diolah menggunakan Rancangan Acak Lengkap (RAL) dengan perlakuan satu faktor, yaitu pemberian pupuk kompos, yang terdiri dari 4 taraf, yaitu $0 \mathrm{gr}, 750$ gr, 1.000 gr, dan 1.21150 gr. Dalam penelitian ini dilakukan uji beda nyata Duncan's (DMRT = Duncan's Multiple Range test).

\section{HASIL DAN PEMBAHASAN}

Pupuk kompos yang berasal dari pengolahan limbah cair (dalam bentuk sludge) mempunyai $\mathrm{pH} 7,64$, nisbah $\mathrm{C} / \mathrm{N}$ ratio adalah 17. Unsur C berperan sebagai pembangun bahan organik karena sebagian besar bahan kering tanaman terdiri dari bahan organik, diambil tanaman berupa $\mathrm{CO}_{2}$. Unsur $\mathrm{N}$ yang diserap oleh tanaman berupa $\mathrm{NO}_{3}$ - dan $\mathrm{NH}_{4}+$. Menurut Soetrisno. K (1996), nitrogen $(\mathrm{N})$ berperan merangsang pertumbuhan vegetatif yaitu menambah tinggi tanaman dan merangsang tumbuhnya anakan.

Dalam penelitian ini dilakukan uji coba pupuk kompos terhadap tanaman Eucalyptus pellita. Pertumbuhan Eucalyptus pellita dapat dilihat berdasarkan parameter yang di amati yaitu tinggi, diameter batang, dan jumlah daun. Pertumbuhan adalah proses dalam kehidupan tanaman yang mengakibatkan perubahan ukuran tanaman semakin besar dan juga menentukan hasil tanaman. Pertambahan ukuran organ tanaman secara keseluruhan merupakan hasil dari pertumbuhan bagian-bagian tanaman akibat dari pertambahan jaringan sel yang dihasilkan oleh pertambahan ukuran sel.

\section{a. Tinggi Tanaman}

Pengamatan terhadap tinggi tanaman dilakukan dengan mengukur tanaman dari pangkal batang sampai batas daun tertinggi secara vertikal menggunakan meteran/penggaris. Rata- rata tinggi tanaman Eucalyptus pellita setelah tanaman berumur 6 bulan dapat dilihat pada gambar 1 . 


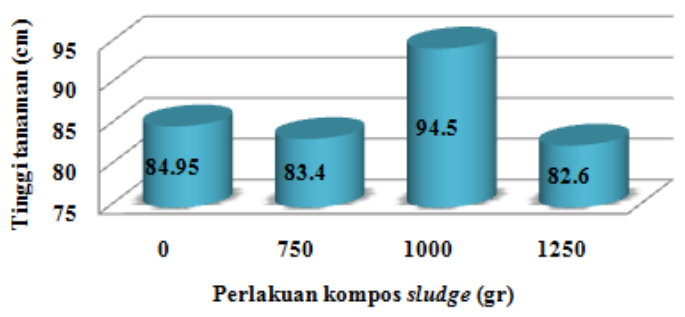

Gambar 1. Histogram Rata-Rata Pertumbuhan Tinggi Tanaman Eucalyptus pellita

Berdasarkan gambar 1 dapat dilihat bahwa perlakuan $1.000 \mathrm{gr}$ merupakan perlakuan yang terbaik karena mampu memberikan pengaruh terhadap tinggi tanaman Eucalyptus pellita sebesar 94,5, $\mathrm{cm}$. Meskipun secara statistik pengaruhnya tidak berpengaruh nyata, sesuai dengan hasil analisis uji $f$, pemberian pupuk kompos sludge sebanyak $1.000 \mathrm{gr}$ diduga telah mampu menyediakan tambahan hara makro maupun mikro yang diperlukan oleh tanaman Eucalyptus pellita selama fase pertumbuhan vegetatif. Respon pertumbuhan tinggi dosis $1.250 \mathrm{gr}(82,6 \mathrm{~cm})$ yang lebih rendah jika dibandingkan dengan dosis $0 \mathrm{gr}(84,95 \mathrm{~cm})$ diduga bahwa dalam kurun waktu 3 bulan penanaman, unsur hara yang terkandung dalam pupuk kompos sludge yang diberikan tersebut belum mampu diserap secara maksimal oleh tanaman sebab belum terurai dengan baik di dalam tanah. Hal ini sesuai dengan Parnata (2010), bahwa salah satu kelemahan pupuk organik adalah kecepatan penyerapan unsur hara oleh tanaman lebih lama dibandingkan dengan penyerapan unsur hara dari pupuk anorganik.

Untuk melihat pertumbuhan tinggi tanaman Eucalyptus pellita setiap minggunya dapat dilihat pada gambar 2 .

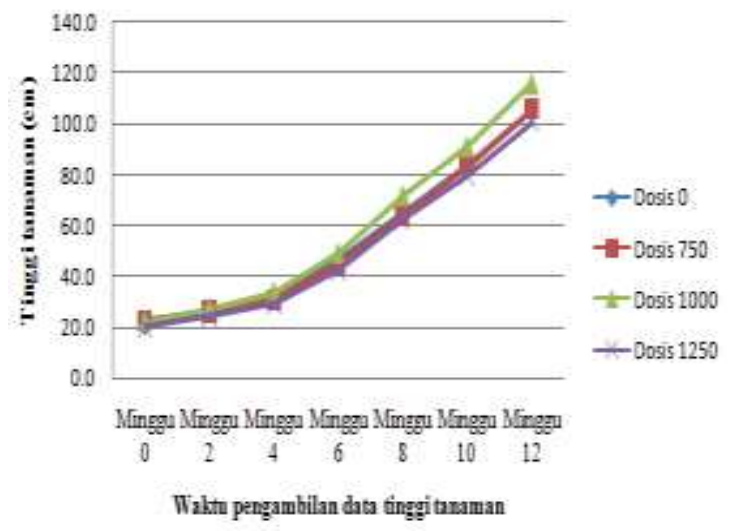

\section{Gambar 2. Grafik Pertumbuhan Tinggi Tanaman Eucalyptus pellita}

Berdasarkan grafik diatas dapat dilihat bahwa pada awal pertumbuhan (minggu ke 6) tanaman mulai mengalami pertumbuhan yang signifikan jika dibandingkan dengan minggu sebelumnya. Diduga pada minggu 
ke-6 penyerapan unsur hara, $(16,45 \mathrm{~mm})$ merupakan perlakuan terutama unsur nitrogen oleh yang terbaik karena mampu tanaman lebih baik dari minggu memberikan pengaruh terhadap sebelumnya. Menurut Soetrisno K, diameter batang tanaman (1996), unsur nitrogen (N) Eucalyptus pellita. Meskipun berperan merangsang secara statistik pengaruhnya tidak pertumbuhan vegetatif yaitu berpengaruh nyata, sesuai dengan menambah tinggi tanaman dan merangsang tumbuhnya anakan.

\section{b. Diameter Tanaman}

Pengamatan

diameter tanaman dilakukan dengan mengukur sisi batang yang berukuran maksimum menggunakan jangka sorong. Rata-rata diameter batang tanaman Eucalyptus pellita yang diamati setelah tanaman berumur 6 bulan dapat dilihat pada gambar 3.

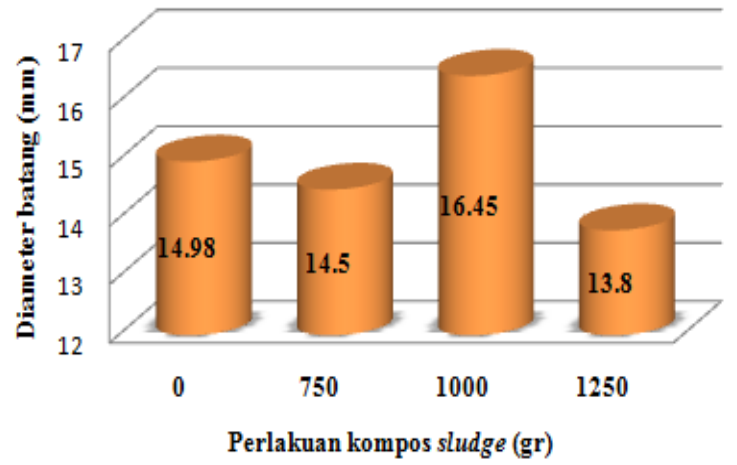

Gambar 3. Histogram Rata-Rata Pertumbuhan Diameter Batang Tanaman Eucalyptus pellita

Berdasarkan gambar 3 dapat dilihat bahwa perlakuan $1.000 \mathrm{gr}$ hasil analisis $u j i \mathrm{f}$, pemberian pupuk kompos sludge sebanyak 1.000 gr diduga telah mampu menyediakan tambahan hara makro maupun mikro yang diperlukan oleh tanaman Eucalyptus pellita selama fase pertumbuhan vegetatif. Respon pertumbuhan diameter batang dosis $1.250 \mathrm{gr}(13,8 \mathrm{~mm})$ yang lebih rendah jika dibandingkan dengan dosis $0 \mathrm{gr}(14,98 \mathrm{~mm})$ diduga bahwa dalam kurun waktu 3 bulan penanaman, unsur hara yang terkandung dalam pupuk kompos sludge yang diberikan tersebut belum mampu diserap secara maksimal oleh tanaman sebab belum terurai dengan baik di dalam tanah. Hal ini sesuai dengan Parnata, (2010) bahwa salah satu kelemahan pupuk organik adalah kecepatan penyerapan unsur hara oleh tanaman lebih lama dibandingkan dengan penyerapan 
unsur hara dari pupuk anorganik. Menurut Soerianegara (1970), pertumbuhan diameter sebenarnya lebih kuat dipengaruhi oleh faktor lingkungan daripada faktor genetik karena pertumbuhan diameter tanaman merupakan fungsi dari ruang tumbuh. Hal ini juga didukung oleh Safuf. E dkk, (2014) bahwa Pertumbuhan diameter batang tanaman dipengaruhi oleh pupuk itu sendiri serta proses fisiologis yang terjadi di dalam tubuh tanaman tersebut, yaitu proses fotosintesis, respirasi, translokasi, dan penyerapan air serta mineral. Proses fisiologis di atas dipengaruhi oleh faktor lingkungan seperti sinar matahari, tanah, angin, dan cuaca.

Untuk melihat pertumbuhan

$\begin{array}{llr}\text { diameter } & \text { batang } & \text { tanaman } \\ \text { Eucalyptus } & \text { pellita } & \text { setiap } \\ \text { minggunya } & \text { dapat dilihat } & \text { pada } \\ \text { gambar } 4 . & & \end{array}$

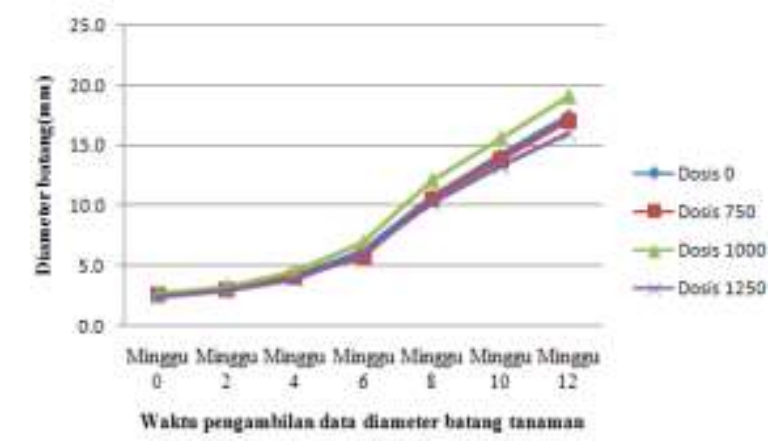

\section{Gambar 4. Grafik Pertumbuhan Diameter Batang Tanaman Eucalyptus pellita}

Berdasarkan grafik diatas dapat dilihat bahwa pada pertumbuhan (minggu ke 6) tanaman mulai mengalami pertumbuhan yang signifikan jika dibandingkan dengan minggu sebelumnya. Diduga pada minggu ke-6 penyerapan unsur hara, terutama unsur kalium oleh tanaman lebih baik dari minggu sebelumnya. Menurut Soetrisno. K (1996), Kalium (K) berperan memperbesar fotosintesis dan membantu pembentukan protein dan karbohidrat serta mengeraskan bagian kayu tanaman. Kekurangan kalium mempengaruhi kecepatan fotosintesis, sintesisprotein, dan respirasi karena itu kalium mungkin memegang peranan pada semua jalur metabolisme. Juga mungkin 
kalium merupakan faktor penting dalam mengatur potensi osmosis sel.

\section{c. Jumlah Daun}

Pengamatan terhadap jumlah daun tanaman dengan menghitung jumlah helai daun pada tiap tanaman. Rata-rata jumlah daun tanaman Eucalyptus pellita yang diamati setelah tanaman berumur 6 bulan disajikan pada gambar 5 .

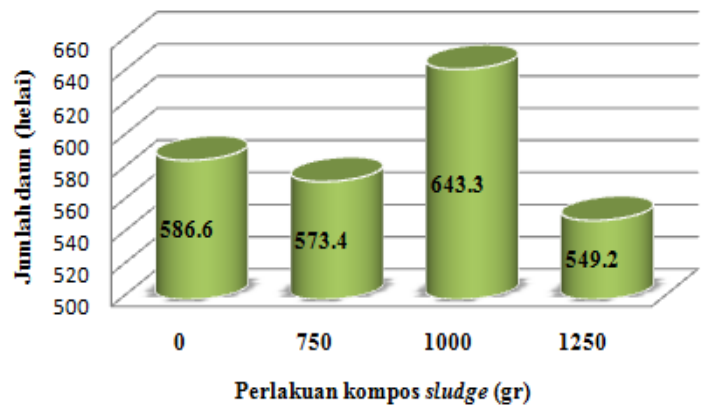

Gambar 5. Histogram Rata Rata Pertumbuhan Jumlah Daun Tanaman Eucalyptus pellita

Berdasarkan gambar 5 dapat dilihat bahwa perlakuan 1.000 gr (643,3 helai) merupakan perlakuan yang terbaik karena mampu memberikan pengaruh terhadap jumlah daun tanaman Eucalyptus pellita. Meskipun secara statistik pengaruhnya tidak berpengaruh nyata, sesuai dengan hasil analisis uji $f$, pemberian pupuk kompos sludge sebanyak
$1.000 \mathrm{gr}$ diduga telah mampu menyediakan tambahan hara makro maupun mikro yang diperlukan oleh tanaman Eucalyptus pellita selama fase pertumbuhan vegetatif. Respon pertumbuhan jumlah daun dosis $1.250 \mathrm{gr}(549,2$ helai) yang lebih rendah jika dibandingkan dengan dosis 0 gr $(586,6$ helai) diduga bahwa dalam kurun waktu 3 bulan penanaman, unsur hara yang terkandung dalam pupuk kompos sludge yang diberikan tersebut belum mampu diserap secara maksimal oleh tanaman sebab belum terurai dengan baik di dalam tanah. Hal ini sesuai dengan Parnata, (2010) bahwa salah satu kelemahan pupuk organik adalah kecepatan penyerapan unsur hara oleh tanaman lebih lama dibandingkan dengan penyerapan unsur hara dari pupuk anorganik. Kelebihan jumlah nitrogen perlu diwaspadai. Ciri-ciri tanaman apabila unsur $\mathrm{N}$ yang yang diserap tanaman berlebih adalah warna daun yang terlalu hijau, tanaman rimbun dengan daun. Hal ini menyebabkan tanaman rentan 
terhadap serangan jamur dan penyakit serta mudah roboh.

Untuk melihat pertumbuhan jumlah daun tanaman Eucalyptus pellita setiap minngunya dapat dilihat pada gambar 6 .

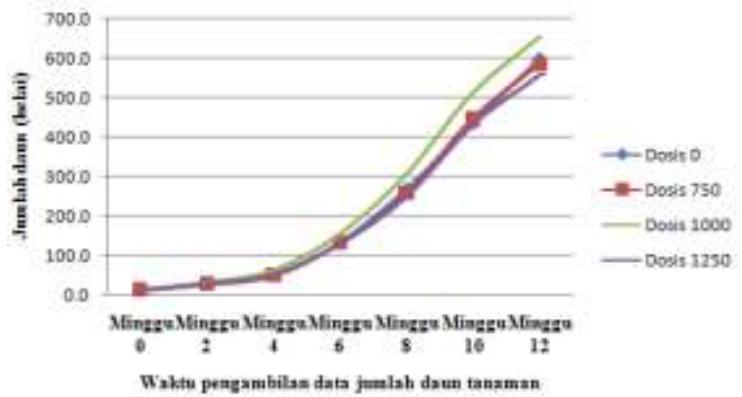

Gambar 10. Grafik Pertumbuhan Jumlah Daun Tanaman Eucalyptus pellita

Berdasarkan grafik diatas
dapat dilihat bahwa pada
pertumbuhan (minggu ke 6)
tanaman mulai mengalami
pertumbuhan yang signifikan jika
dibandingkan dengan minggu
sebelumnya. Diduga pada minggu
ke-6 penyerapan unsur hara,
terutama unsur nitrogen oleh
tanaman lebih baik dari minggu
sebelumnya. Menurut Firmansyah
et al. (2017) fungsi unsur $\mathrm{N}$ beserta
$\mathrm{P}$ dan $\mathrm{K}$ berkaitan erat dengan
proses fotosintesis tanaman.

\section{KESIMPULAN DAN SARAN}

Pemberian pupuk kompos dari pengolahan limbah pulp dan kertas dengan dosis 0, 750, 1000 dan 1250 gr tidak memberi pengaruh terhadap pertumbuhan tinggi, diameter dan jumlah daun Eucalyptus pellita. Dosis pupuk yang paling baik tidak ditentukan karena semua perlakuan tidak berpengaruh nyata pada pertumbuhan tanaman. Namun dari semua perlakuan, Dosis 1.000 gr adalah dosis yang paling baik secara visual.

Perlu dilakukan penelitian lanjut untuk mendapatkan dosis yang berpengaruh nyata terhadap pertumbuhan tanaman Eucalyptus pellita. Penggunaan Pupuk kompos dari limbah industri pulp dan kertas perlu dicoba pada tanaman selain Eucalyptus pellita.

\section{DAFTAR PUSTAKA}

Firmansyah I, M Syakir, dan L Lukman. 2017. Pengaruh kombinasi dosis pupuk $\mathrm{N}, \mathrm{P}$, dan $\mathrm{K}$ terhadap pertumbuhan dan hasil tanaman terung (Solanum melongena $\mathrm{L}$ ). J.Hort. Vo. 27 No.1Juni 2017 :69-78. (http://ejurnal.litbang.pertania n.go.id/index.php/jhort/article/ viewFile/7449/6567 ) 
Komarayati S dan Gusmailina. 2007. Pemanfaatan limbah padat industry pulp untuk pupuk organik. Jurnal Penelitian Hasil Hutan Vol.25 No.2 (http://ejournal.fordamof.org/ejournallitbang/index.php/JPHH/articl e/view/3757 diakses tanggal 5 Mei 2017)

Parnata SA, 2010. Meningkatkan hasil panen dengan pupuk organik. Jakarta. PT Agromedia Pustaka.

Soetrisno K. 1996. Silvikultur. Samarinda. Fakultas Kehutanan, Universitas Mulawarman

Soerianegara. I. 1970. Pemuliaan Hutan. Laporan No 104. Lembaga Penelitian Hutan Bogor. 